\title{
Profitability Analysis of Small Scale Irrigation Technology Adoption to Farmers in Nasho Sector, Rwanda
}

\author{
Eliezel Habineza 1,2, Jean Nepomuscene Nsengiyumva3 ${ }^{3}$ Eric Ruzigamanzi ${ }^{4}$, \\ Martin Vincent Nsanzumukiza ${ }^{*}$
}

\begin{abstract}
${ }^{1}$ SMART-Agricultural Engineering Program, Department of Bio-Resources and Rural Systems Engineering, General Graduate School, Hankyong National University, Anseong, South Korea

${ }^{2}$ Department of Land Husbandry, Irrigation Research and Technology Transfer, Rwanda Agriculture and Animal Resources Development Board, Kigali, Rwanda

${ }^{3}$ Department of Irrigation and Drainage, School of Agriculture Engineering, University of Rwanda, Nyagatare, Rwanda ${ }^{4}$ Department of Department of Agricultural and Resources Economics, School of Agriculture and Environmental Sciences, Jomo Kenyatta University, Kigali Campus, Kigali, Rwanda

${ }^{5}$ Department of Environmental Economics and Natural Resources Management, Faculty of Environmental Studies, University of Lay Adventists of Kigali, Kigali, Rwanda
\end{abstract}

Email: ^nsanzumumartiv@gmail.com

How to cite this paper: Habineza, E., Nsengiyumva, J.N. Ruzigamanzi, E. and Nsanzumukiza, M.V. (2020) Profitability Analysis of Small Scale Irrigation Technology Adoption to Farmers in Nasho Sector, Rwanda. Journal of Agricultural Chemistry and Environment, 9, 73-84.

https://doi.org/10.4236/jacen.2020.92007

Received: March 21, 2020

Accepted: May 4, 2020

Published: May 7, 2020

Copyright $\odot 2020$ by author(s) and Scientific Research Publishing Inc. This work is licensed under the Creative Commons Attribution International License (CC BY 4.0).

http://creativecommons.org/licenses/by/4.0/ (c) (i) Open Access

\begin{abstract}
The study aims to assess the effect of small scale irrigation adoption to farmers in Nasho sector, Kirehe District in Rwanda. The average yield was $12,309.73 \mathrm{Kg} / 2.62 \mathrm{ha}$ or $4698.73 \mathrm{Kg} / \mathrm{ha}$ for adopters with the mean difference between adopters and non adopters ranged from $2819.63 \mathrm{Kg}$ to $4766.59 \mathrm{Kg}$ per unit area of production. For food security status, the average mean quantity of maize consumed at home level was $615.54 \mathrm{Kg}$ with the mean difference ranged from $377.29 \mathrm{Kg}$ to $474.68 \mathrm{Kg}$. For market participation, the average treatment effect of the treated (ATT) of quantity of maize sold was 11,694.24 $\mathrm{Kg}$ while the mean difference ranged from $7165.98 \mathrm{Kg}$ to $9015.60 \mathrm{Kg}$. The Average Treatment Effect of the Treated market price was $213 \mathrm{Frws} / \mathrm{Kg}$ while the mean difference ranged from $44.51 \mathrm{Frws} / \mathrm{Kg}$ to $48.3053 \mathrm{Frws} / \mathrm{Kg}$. The Average Treatment Effect of the Treated of farmer's revenues for the users was 938,772 Frws/ha, however, the mean difference between adopters and non adopters ranged from 1,732,942 Frws to 2,007,039 Frws. The Average Treatment Effect of the Treated of farmer's net farm income was 1,066,393 Frws while mean difference between users and non users ranged from 803,967 Frws to 854,141 Frws. For profitability analysis, the cost benefit ratio (CBR) was taken into account. The total benefit per unit area was 2,434,509 Frws and total average mean cost of $1,382,313$ Frws and $\mathrm{CBR}=1.761>1$. The
\end{abstract}


findings of this study will help the policy makers for deeper sector planning and also, it will facilitate other stakeholders to invest in irrigation technology to improve the livelihoods of Rwandan farmers and other surroundings.

\section{Keywords}

Profitability, Small Scale İrrigation, Propensity Score Matching, Farmers, Treatment Effect

\section{Introduction}

Irrigated agriculture in Africa is under renewed attention in relation to food security and poverty reduction [1]. It is widely acknowledged to play a major role in improving productivity, reducing poverty and sustaining rural livelihoods. It enables households to generate more income, increase their resilience and, in some cases, transform their livelihoods [2]. Irrigation contributes to agricultural growth and reduces poverty directly through permitting intensification and diversification, hence increased outputs and incomes; increasing agricultural wage employment; and reducing local food prices. Irrigation has contributed significantly to poverty alleviation, food security, and improving the quality of life for rural populations [3]. However, the sustainability of irrigated agriculture is being questioned, both economically and environmentally. The increased dependence on irrigation has not been without its negative environmental effects. Inadequate attention to factors other than the technical engineering and projected economic implications of large-scale irrigation or drainage schemes in Africa has frequently led to great difficulties. Decisions to embark on these costly projects have often been made in the absence of sound objective assessments of their environmental and social implications [4]. Major capital intensive water engineering schemes have been proposed without a proper evaluation of their environmental impact and without realistic assessments of the true costs and benefits that are likely to result [5] [6].

Water is a valuable resource in agricultural food production while it remains a finite resource, the competition of this precious resource is highly increasing due to the current and future events such as rapid increase in world population which is expected to reach 9 billion by 2050 [7]. To understand the role of irrigation in income growth and poverty alleviation, it is useful to review the fundamental sources of economic growth. According to [8], there are three major sources of economic growth. The first major is related to an increase in the amounts of inputs used in production. Additional inputs can move a country out of its aggregate production function to a higher level of output. The third major inputs in the development process which are population growth (which affects labor availability and labor), natural resource availability (which affects the cost of environmental factors such as land with its associated soils, water, and forest), and capital accumulation (which affects the availability of man-made 
inputs).

Rwanda has a tropical-temperate climate with a bimodal rainfall pattern with peaks in the months of April and November. Agriculture accounts for $25 \%$ of national GDP in the year of 2019 and provides employment around $70 \%$ of the population. Irrigated agriculture has long played a key role in feeding expanding populations and is undoubtedly destined to play a still greater role in the future for mitigation of drought and climate change issues. The current status of the area developed with formal irrigation infrastructure is around 56,000 ha which is equal to $9.5 \%$ of total potential irrigable area which is 589,711 ha $(47 \%$ is in marshland \& $53 \%$ is on hillside). Rwanda has three agricultural seasons namely (A, B and C): Season A starts in September to January each year, the main crops are maize, beans and soybeans. The Season B starts in March to July each year with the main crops such as maize, beans, soybeans, Irish and sweet potatoes and cassava, however, the agricultural season (C) which actually starts in June to August, that is indubitably reserved for vegetables production in marshlands under irrigation practices. Based on availability of water bodies, river and lakes stationed at Nasho sector, variety of crops are grown in all three Season under Nasho irrigation schemes, Therefore, this research was intended to compare cost and benefits of farmers' adopters of irrigation technology in two consecutive farming seasons A and B. To come up with better expected outcomes, the study focuses primarily on the Effect of small scale irrigation adoption to farmers' revenues and Compare the costs and benefits accrued in adoption of small scale irrigation in the study area.

\section{Material and Methods}

The study was conducted in Eastern province of Rwanda at Nasho sector during the agricultural season of 2017A (started September 2016 ended January 2017) and agricultural season 2017B (started march 2017 ended June 2017) to assess the effectiveness of small scale irrigation adoption among small scale farmers in Rwanda. Multistage sampling techniques were used to select 317 farmers including adopters and non-adopters of Small Scale Irrigation Technology SSIT. Descriptive statistics not limited to frequency but also to means, standard deviation, Standard errors were also used to characterize farmers' characteristics while T-test was used to compare means of respondents. Propensity score matching (PSM) and Cost Benefit Ratio methods were employed to estimate effect of small scale irrigation technology adoption using STATA version 13.0.

\subsection{Study Areas Description}

The present study was conducted in Nasho sector of Kirehe district, Figure 1 with the total population of 26,954 habitants where several types of irrigation activities are undertaken [9] and these included sprinkler irrigation, drip irrigation and pivot center irrigation under Buffet project. Kirehe District is located in the southern part of Eastern Province; it is the one of seven districts of Eastern 


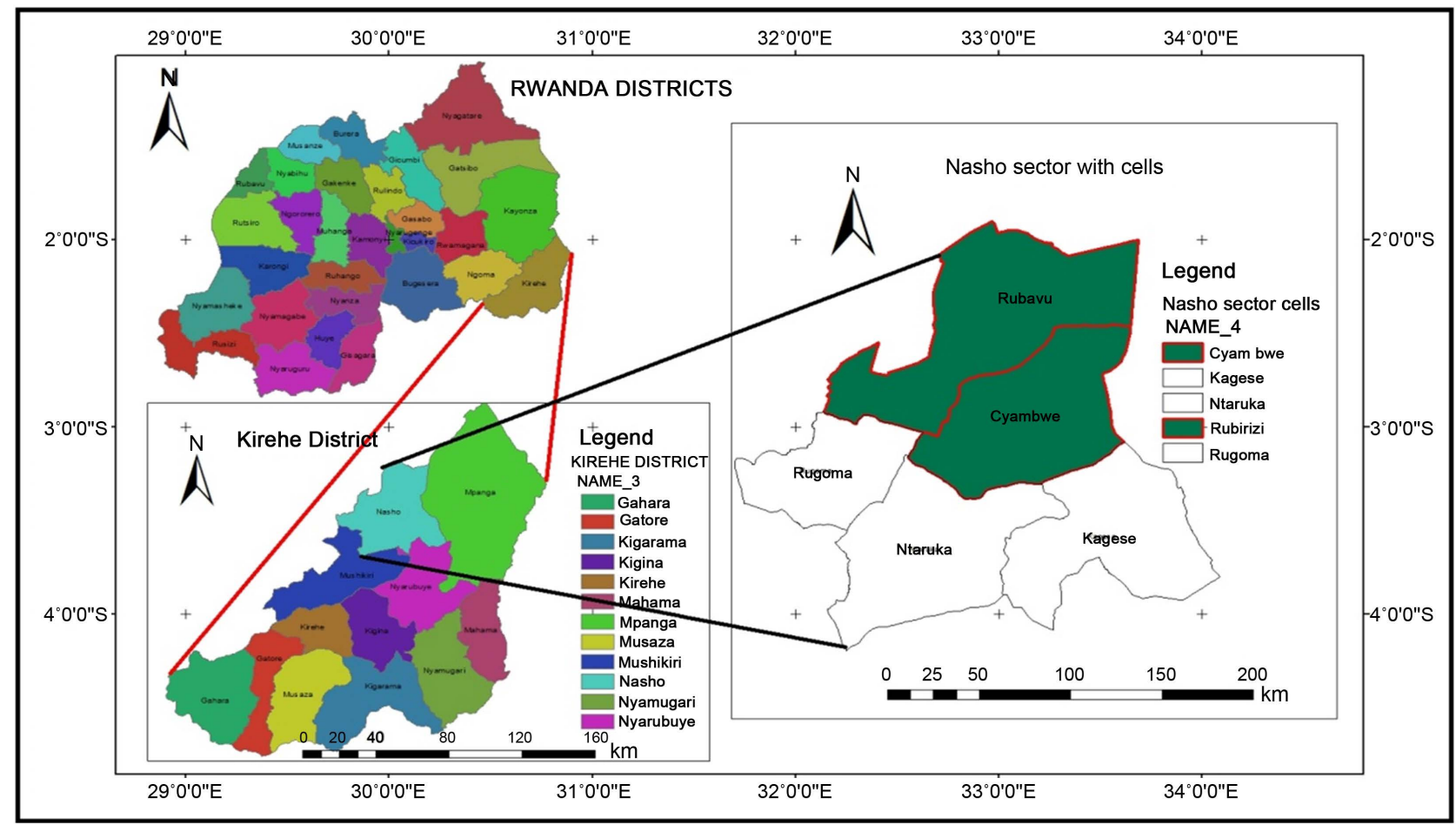

Figure 1. Nasho map indicating the study area under irrigation scheme.

province where Crop Intensification Programme (CIP) is acquired from 2007. It is the one of the driest districts in the country (areas in the east receive on average less than $900 \mathrm{~mm}$ of rain per year) [10]. The average rainfall for Rwanda is $1250 \mathrm{~mm}$ per annum and it is the hottest in the country: Eastern parts of the district record average temperatures of more than 21 degrees Celsius (MINAGRI, 2012a) against the national average of 19 degrees Celsius (MINAGRI, 2012a) cited by [10]. Classifications of the actual capability of the district for agriculture reveal differentiation across the district, with some parts able to support crops due to availability of water resources like rivers but due to the climate conditions the farmers are suffering of the drought due the weather conditions. Currently the total area under covered by new irrigation project is about 1280 ha in Nasho sector, Kirehe District of Eastern Province, the figure below shows Nasho sector localization in the map of Rwanda and have been produced by using Arc GIS 10.3.1 computer package.

\subsection{Sampling and Data Collection Techniques}

The study used primary data from 193 respondents from COVAMIS cooperative staff, Buffet irrigation project beneficiaries and other individual farmers adopted irrigation technology. This study covered mainly farmers using irrigation technology as treated variable and farmers' non applying water in the farmed crops as control factor. Three multi-stage sampling techniques were used to select respondents from the selected districts. In the first stage purposive sampling was used to select the farmers using irrigation technology during maize production. 
In the final stage the selection of small scale farmers growing maize in the study area by means of simple random sampling to select farmers from each of the preselected site or perimeter zone. The total population under the study was 330 maize growers including adopters and non adopters of small scale irrigation technology in the study area. The sample size was calculated from a population on which an investigation was conducted. Slovin's Formula adapted by Ryan, 2013 provides the sample size $(n)$ using the known population size $(N)$ and the acceptable error value (e). The sample size will be determined by using Ryan formula [11]

$$
n=\frac{N}{1+\alpha^{2} N}
$$

where $n$ is the sample size from the Nasho irrigation scheme zone, $\alpha$ is the marginal error and $N$ is the total population from the study area. The total population from the study comprises individual farmers from Nasho sector and other cooperative members from COVAMIS. The study will consider the confidence interval of $95 \%$ and margin error of $5 \%$ respectively. Then the sample size from this study will be given in Equation (2).

$$
n=\frac{330}{1+0.05^{2} \times 330}=186
$$

\section{Application of Propensity Score Matching (PSM)}

Based on Background and objective of the study, the Propensity Score Matching (PSM) model was used to estimate propensity score matching for adopters and non adopters of SSIT in Nasho irrigation scheme. Equation (1) describes the Propensity Score Matching (PSM) PSM models between adopters and non adopters of small scale irrigation technology:

$$
\begin{aligned}
\mathrm{ATT} & =E\left(\Delta_{i} \mid I_{i}=1\right)=E\left[Y_{1 i}-Y_{0 i} \mid I_{i}=1\right] \\
& =E\left[Y_{1 i} \mid I_{i}=1\right]-E\left[Y_{0 i} \mid I_{i}=1\right]
\end{aligned}
$$

From Equation (1), $E\left[Y_{0 i} \mid I_{i}=1\right]$ is the missing data representing the outcomes of participants in the absence of irrigation? One way to estimate this missing data is to use outcomes of a non-irrigating group. By using the outcomes of non-irrigating farmers, Equation (3) can be rewritten as

$$
\underbrace{E\left(\Delta_{i} \mid I_{i}=1\right)=E\left[Y_{1 i} \mid I_{i}=1\right]-E\left[Y_{0 i} \mid I_{i}=1\right]}_{\text {Bias }}
$$

Without controlling for the unobservable heterogeneity, Equation (2) can be shown to consist of a bias in addition to the impact estimate. Subtracting and adding right hand side of Equation (5) gives:

$$
\begin{gathered}
=E\left[Y_{1 i} \mid I_{i}=1\right]-E\left[Y_{0 i} \mid I_{i}=0\right]-E\left[Y_{0 i} \mid I_{i}=1\right]+E\left[Y_{0 i} \mid I_{i}=1\right] \\
=E\left[Y_{1 i}-Y_{0 i} \mid I_{i}=1\right]+E\left[Y_{0 i} \mid I_{i}=1\right]-E\left[Y_{0 i} \mid I_{i}=0\right]
\end{gathered}
$$

Rearranging (4) gives:

$$
=E\left[\Delta_{i} \mid I_{i}=1\right]+E\left[Y_{0 i} \mid I_{i}=1\right]-E\left[Y_{0 i} \mid I_{i}=0\right]
$$


where ATT is the average treatment effect on the treated farmers with adoption of small scale irrigation technology in which $Y_{1}$ are adopters of SSIT and $Y_{0}$ are non adopters of SSIT respectively. The dependent variable in this model is a binary variable/dummy variable where a farmer was prompt to adopt small scale irrigation for crop production in the season of 2017A and 2017B. The potential outcome framework is used to estimate the effect of small scale irrigation adoption among small scale farmers in Rwanda: Evidence from Nasho Irrigation Scheme. Here the treatment is a farmer adopted SSIT in crop production system $j$. Let $D_{j}$ be the binary variable indicating the farmer with production $j$ with $D_{j}=$ 1 indicating the farmer adopted SSIT and $D_{j}=0$ indicating non counter factual by a population unit. Also, let $y_{1} \equiv g\left(d_{j}^{1}, z\right)$ and $y_{0} \equiv g(0, z)$ be the potential outcomes corresponding to the two mutually exclusive states of farmer adopted small scale irrigation technology (SSIT) and their counter parties (non-adopter of SSIT), respectively. For any population unit, the causal effect of SSIT adoption on the outcome $y$ is defined as $y=y_{1}-y_{0}$. However, the two potential outcomes cannot be observed at the same time. With the observed outcome $y$ given by $y=D_{j} y_{1}+\left(1-D_{j}\right) y_{0}$, we can only observe either $y_{1}$ or $y_{0}$ depending on whether $D_{j}$ equal 1 or 0 , thus making it impossible to measure $y_{1}-y_{0}$ for any population unit. However, if we let $Y$ be the random variable defined in some probability space $(\Omega, \Sigma, P)$ reflecting the distribution in the population of the outcome represented by the outcome variable $y_{1}$, then the average causal effect of adoption in the population, $E\left(Y_{1}-Y_{0}\right)$ (with $E$ being the mathematical expectation operator), can be determined. Such a population parameter is called the average treatment effect (ATE) in the literature.

\section{Results and Discussion}

In this study, econometric data analysis is clearly applied to estimate the effect of small scale irrigation technology (SSIT) adoption in Rwanda using Propensity Score Matching (PSM) through Average Treatment Effect on the Treated (ATT) three estimation algorithms Nearest Neighbour Matching (NNM), Kernel Matching (KM) and Radius Matching (RM) algorithms. We directed our survey on the household level both for adopters and non adopters of small scale Irrigation technology adoption, such that all the income generated from the maize crop farms in a household were summed up as main gross crop income generator. We took note of the average sales from maize production of sampled farmers that they made during harvest and after harvest. Similarly, the unsold produce was valued as consumed quantity by farmer household levels regardless the current market price. This formed the total gross crop income of a particular household. On the other hand, the total cost of production per farm included the variables' costs such as labor costs, seeds, fertilizers (DAP, UREA and Organic compost), and transportation costs. The crop income for a particular farm was computed by including the total costs from gross income. Further, net farm income was calculated from differentiation of gross farm revenues to total cost of production. 


\subsection{Average Treatment Effect on the Treated (ATT) Estimates on Effect of SSIT Adoption on Household Revenues}

Worldwide, several researchers have worked on the effect small scale irrigation technology on farmer's revenues and food security through the use of Propensity score matching (PSM). For instance [12] evaluated the micro irrigation effect on households food security and found that non adopters always aims to be the poorest. Thus, the expectation of the households without treatment of micro irrigation would have had lower income as a result of the sample selection bias occurs due to the self-election mechanism. Moreover [13] confirmed that the welfare variety between the treated as well as the control group would not be attributed to irrigation access as long as the selection bias exists. So using the non-parametric matching estimation method, the impact of small scale irrigation on the household income would be proved whether using of small scale irrigation have a significant difference between the treated and control group. The results from nearest neighbor, kernel, and radius matching methods are used to estimate average quantity of maize supplied to markets, market price, revenues and net farm income and the mean difference as program impact for adopters of irrigation technology compared to control were presented and discussed through ATT covariates estimates. The average treatment effect of the treated (ATT) of maize sold for adopters of small scale irrigation technology was 11,694.24 Kg and the mean difference (MD) ranged from $9015.60 \mathrm{Kg} ; 8388.39 \mathrm{Kg}$ and 7165.98 $\mathrm{Kg}$ of small scale irrigation technology adopters using Nearest Neighbour Matching (NNM), Kernel Matching (KM) and Radius Matching (RM) accordingly and all estimates are statistically significantly at $2.19^{\star *} ; 1.91^{\star *}$ and $1.82^{\star *}$ at $5 \%$ level of significance respectively.

Price was the key market factor participation. Results from the PSM based on three matching algorithms revealed that the ATT market price was $213 \mathrm{Frws} / \mathrm{Kg}$ while the mean difference for the adopters of SSIT program ranged from 44.53 Frws/Kg; 48.3053 Frws/Kg and 44.51 Frws/Kg using NNM, KM and RM and all estimates were statistically significant with t-stat of $2.16^{\star *} ; 2.2^{* \star}$ and $2.25^{\star *}$ at $5 \%$ level of significance respectively. Good market price leads to high farmer's revenues useful to predict the next farming season.

The results indicate that participating in small scale irrigation significantly increases household income as shown by a positive estimated coefficient of small scale irrigation use with a t-value less than 5\%, Table 1. PSM results indicated that the ATT of the expected revenues for the users (treated) of SSIT was 2,459,582.86 Frws/u.a either 938,772 Frws/ha of maize for adopters of small scale irrigation technology and the mean difference between adopters and non adopters ranged from 2,007,039 Frws; 1,921,407 Frws and 1,732,942 Frws of small scale irrigation technology adopters using $\mathrm{NN}, \mathrm{KM}$ and $\mathrm{RM}$ accordingly and all estimates are statistically significantly at $3.24^{\star *} ; 2.92^{\star *}$ and $2.92^{\star *}$ at $5 \%$ level of significance respectively by considering the working unit area under crop farming. 
Table 1. Effect of small scale irrigation adoption to farmers' revenues.

\begin{tabular}{|c|c|c|c|c|c|c|}
\hline \multicolumn{7}{|c|}{ Nearest Neighbour Matching (NNM) } \\
\hline Variable & Sample & Treated & Controls & Difference & S.E. & T-stat \\
\hline \multirow[t]{2}{*}{ Quantity sold (Kg) } & Unmatched & $11,694.24$ & 3380.74 & 8313.50 & 1559.23 & $5.33^{* *}$ \\
\hline & ATT & $11,694.24$ & 2678.64 & 9015.60 & 4117.76 & $2.19^{* *}$ \\
\hline \multirow[t]{2}{*}{ Price (Frws/1Kg) } & Unmatched & 213.38 & 206.43 & 6.95 & 9.93 & 0.7 \\
\hline & ATT & 213.38 & 168.84 & 44.53 & 20.59 & $2.16^{* *}$ \\
\hline \multirow[t]{2}{*}{ Revenues (Frws) } & Unmatched & $2,459,582.86$ & $611,949.04$ & $1,847,633.83$ & $335,624.86$ & $5.51^{\star *}$ \\
\hline & ATT & $2,459,582.86$ & $452,543.57$ & $2,007,039.29$ & $619,512.67$ & $3.24^{* *}$ \\
\hline \multirow[t]{2}{*}{ Net Farm Income } & Unmatched & $1,066,392.86$ & $272,800.18$ & $793,592.68$ & $180,372.65$ & $4.4^{\star *}$ \\
\hline & ATT & $1,066,392.86$ & $212,252.13$ & $854,140.73$ & $141,329.86$ & $6.04^{* *}$ \\
\hline \multicolumn{7}{|c|}{ Kernel Matching } \\
\hline \multirow[t]{2}{*}{ Quantity sold (Kg) } & Unmatched & $11,694.24$ & 3380.74 & 8313.50 & 1559.23 & $5.33^{* *}$ \\
\hline & ATT & $11,694.24$ & 3305.85 & 8388.39 & 4387.29 & $1.91^{\star *}$ \\
\hline \multirow[t]{2}{*}{ Price (Frws/1Kg) } & Unmatched & 213.38 & 206.43 & 6.95 & 9.93 & 0.7 \\
\hline & ATT & 213.38 & 165.08 & 48.30 & 21.91 & $2.2^{* *}$ \\
\hline \multirow[t]{2}{*}{ Revenues (Frws) } & Unmatched & $2,459,582.86$ & $611,949.04$ & $1,847,633.83$ & $335,624.86$ & $5.51^{* *}$ \\
\hline & ATT & $2,459,582.86$ & $538,175.37$ & $1,921,407.49$ & $658,944.24$ & $2.92^{* \star}$ \\
\hline \multirow[t]{2}{*}{ Net Farm Income } & Unmatched & $1,066,392.86$ & $272,800.18$ & $793,592.68$ & $180,372.65$ & $4.4^{\star *}$ \\
\hline & ATT & $1,066,392.86$ & $225,798.84$ & $840,594.03$ & $148,037.48$ & $5.68^{* *}$ \\
\hline \multicolumn{7}{|c|}{ Radius Matching (RM) } \\
\hline \multirow[t]{2}{*}{ Quantity sold (Kg) } & Unmatched & $11,694.24$ & 3380.74 & 8313.50 & 1559.23 & $5.33^{* *}$ \\
\hline & ATT & $11,694.24$ & 4528.26 & 7165.98 & 3946.28 & $1.82^{* \star}$ \\
\hline \multirow[t]{2}{*}{ Price (Frws/1Kg) } & Unmatched & 213.38 & 206.43 & 6.95 & 9.93 & 0.7 \\
\hline & ATT & 213.38 & 168.87 & 44.51 & 19.74 & $2.25^{* *}$ \\
\hline \multirow[t]{2}{*}{ Revenues (Frws) } & Unmatched & $2,459,582.86$ & $611,949.04$ & $1,847,633.83$ & $335,624.86$ & $5.51^{* *}$ \\
\hline & ATT & $2,459,582.86$ & $726,640.95$ & $1,732,941.91$ & $594,462.66$ & $2.92^{* *}$ \\
\hline \multirow[t]{2}{*}{ Net Farm Income } & Unmatched & $1,066,392.86$ & $272,800.18$ & $793,592.68$ & $180,372.65$ & $4.4^{\star \star}$ \\
\hline & ATT & $1,066,392.86$ & $262,426.25$ & $803,966.61$ & $137,125.01$ & $5.86^{* *}$ \\
\hline
\end{tabular}

The findings support the conclusion that availability of small scale irrigation does improve household income, indicating that small scale irrigation users earned net farm income as ATT value of 1,066,393 Frws for the treated and mean difference between users and non users ranged from 854,141 Frws; 840,594 Frws and 803,967 Frws of small scale irrigation technology adopters more than the non-participants depending on the matching method used NN, KM and RM accordingly and all estimates are statistically significantly at $6.04^{* *} ; 5.68^{\star *}$ and $5.86^{* *}$ at $5 \%$ level of significance respectively. Based on findings, his result is consistent with the findings of previous studies [14] that found even though smallholder irrigation has admittedly failed as many schemes have collapsed, 
those irrigation schemes that remain operational are playing an important role in rural poverty reduction.

\subsection{Comparison of Costs and Benefits Accrued in Adoption of Small Scale Irrigation Technology}

To conduct the comparison between the cost and benefits of the adopters and non adopters of small scale irrigation technology, the cost benefits analysis was used to compute the Cost Benefit Ratio for project appraisal. The costs considered included the cost of fertilizers and labor cost paid in maize production and post harvest operations. For the adopters of small scale irrigation technology, the maize producers farmers on an average per unit area earned during study, on benefits ranging from 351,788 Frws to 7,441,667 Frws with the average mean of total benefit per unit area of the gross profit of 2,434,509 Frws and total average mean cost of $1,382,313$ Frws on average with the Cost-Benefit Ratio CBR = $1.761>1$ indicating viable business. For the non adopters of small scale irrigation technology, the earned benefits ranged from 50,333 Frws to 7,032,375 Frws with the average mean of total benefit of 611,949 Frws against total average mean cost of 339,149 Frws while the cost benefit ratio (CBR) for non users of SSIT was $\mathrm{CBR}=1.804>1$ indicating also that maize business venture is a viable project. The higher Cost Benefits Ratio (CBR), the lower cost invested due to no investment in irrigation equipment and tools. The findings also indicated that the pooled average mean benefit for all sampled respondents was 2,160,145 Frws while the pooled cost benefits ratio of between benefit and cost was CBR of $1.763>1$, indicating that the maize farming under irrigation is more profitable due to its profitability index greater than one (Table 2).

Table 2. Costs and benefits accrued in adoption of small scale irrigation in the study area.

\begin{tabular}{|c|c|c|c|c|c|c|c|c|c|c|c|}
\hline & \multirow[b]{2}{*}{ Parameters } & \multicolumn{10}{|c|}{ Comparison of production cost versus Benefits } \\
\hline & & $\begin{array}{l}\text { Cost } \\
\text { DAP }\end{array}$ & Cost-Urea & Cost-Organic & $\begin{array}{l}\text { Cost-Land } \\
\text { Preparation }\end{array}$ & Cost-Sowing & Cost-Weeding & Cost-PHHS & Cost-Irrig & $\begin{array}{l}\text { Total } \\
\text { Cost }\end{array}$ & Benefits \\
\hline \multirow{6}{*}{ 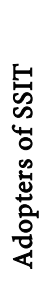 } & Mean & 142,915 & 59,764 & 51,969 & 311,814 & 103,938 & 64,961 & 129,923 & 518,359 & $1,382,313$ & $2,434,509$ \\
\hline & Std. Err & 7288.438 & 3047.89 & 2650.338 & $311,814.3$ & 5300.681 & 3312.927 & 6625.851 & $26,635.41$ & $70,890.27$ & $133,464.2$ \\
\hline & Std. Dev & $91,614.25$ & $38,311.38$ & $33,314.23$ & $199,885.6$ & $66,628.53$ & $41,642.85$ & $83,285.65$ & 334,802 & $891,076.9$ & $1,677,619$ \\
\hline & Min & 37,333 & 15,612 & 13,576 & 81,455 & 27,152 & 16,970 & 33,939 & 67,879 & 226,036 & 351,788 \\
\hline & Max & 453,750 & 189,750 & 165,000 & 990,000 & 330,000 & 206,250 & 412,500 & $1,650,000$ & $4,397,250$ & $7,441,667$ \\
\hline & $\mathrm{N}$ & 158 & 158 & 158 & 158 & 158 & 158 & 158 & 158 & 158 & 158 \\
\hline & CBR & & & & & & & & & \multicolumn{2}{|c|}{1.761} \\
\hline & Mean & 41,644 & $17,414.75$ & $15,143.29$ & $90,859.68$ & $30,286.58$ & $18,929.14$ & $37,858.29$ & 87,013 & $339,148.8$ & 611,949 \\
\hline 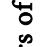 & Std. Dev & $106,326.8$ & $44,463.92$ & $38,664.27$ & $231,985.7$ & $77,328.56$ & $48,330.35$ & $96,660.69$ & $399,589.9$ & $1,042,329$ & $1,281,163$ \\
\hline 苋 & Min & 4000 & 1673 & 1455 & 8727 & 2909 & 1818 & 3636 & 0 & 24,218 & 50,333 \\
\hline 芩 & $\operatorname{Max}$ & 577,500 & 241,500 & 210,000 & $1,260,000$ & 420,000 & 262,500 & 525,000 & $2,100,000$ & $5,596,500$ & $7,032,375$ \\
\hline \multirow[t]{2}{*}{ : } & $\mathrm{N}$ & 28 & 28 & 28 & 28 & 28 & 28 & 28 & 28 & 28 & 28 \\
\hline & CBR & & & & & & & & & \multicolumn{2}{|c|}{1.804} \\
\hline
\end{tabular}




\section{Continued}

\begin{tabular}{|c|c|c|c|c|c|c|c|c|c|c|c|}
\hline \multirow{7}{*}{ 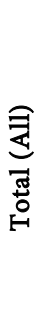 } & Mean & $127,669.8$ & $53,389.21$ & $46,425.39$ & $278,552.3$ & $92,850.77$ & $58,031.73$ & $116,063.5$ & $453,425.5$ & $1,225,278$ & $2,160,145$ \\
\hline & Std. Err & $7,365.784$ & 3080.235 & 2678.464 & $16,070.8$ & 5356.932 & 3348.083 & 6696.164 & $27,664.63$ & $72,301.31$ & $128,160.2$ \\
\hline & Std. Dev & $100,455.9$ & $42,008.81$ & $36,529.38$ & $219,176.5$ & $73,058.82$ & $45,661.77$ & $91,323.5$ & $377,295.2$ & $986,058.4$ & $1,747,873$ \\
\hline & Min & 4000 & 1673 & 1455 & 8727 & 2909 & 1818 & 3636 & 0 & 21,191 & 50,333 \\
\hline & Max & 577,500 & 241,500 & 210,000 & 1260,000 & 420,000 & 262,500 & 525,000 & $2,100,000$ & $5,596,500$ & $7,441,667$ \\
\hline & $\mathrm{N}$ & 186 & 186 & 186 & 186 & 186 & 186 & 186 & 186 & 186 & 186 \\
\hline & CBR & & & & & & & & & \multicolumn{2}{|c|}{1.763} \\
\hline
\end{tabular}

\subsection{Distribution of Density of Propensity Score Estimates over Treated and Controls Group}

Based on information presented on Figure 2; the results of the covariate balancing test to verify the hypothesis that both groups have the same distribution in covariates after matching. The density distribution of the propensity scores for participants and non-participants is shown in Figure 2. The bottom half of each graph shows the propensity score distribution for the non-treated, while the upper-half refers to the treated individuals. It presents the covariates' means, their $\mathrm{t}$-test of differences in means as well as the percentage bias before and after matching, for all covariates, the matched sample means are not almost similar for both the treatment and the control groups therefore indicating the unbalanced matching.

Figure 2 shows that there are no treated individuals out off support region, indicating that all the treated group or individual in area of the study (Nasho irrigation scheme) gets an appropriate match among the non users of Small Scale Irrigation Technology adoption. From the point view, there are some untreated individuals on non users of Small Scale Irrigation Technology found out of the support region hence all untreated individuals were not found within the same region of common support indicating that also all treated and untreated individuals have not received the same propensity score. Thus, findings suggest that there no satisfaction of balancing testing of common region support (assumption of common support was not satisfied) [15].

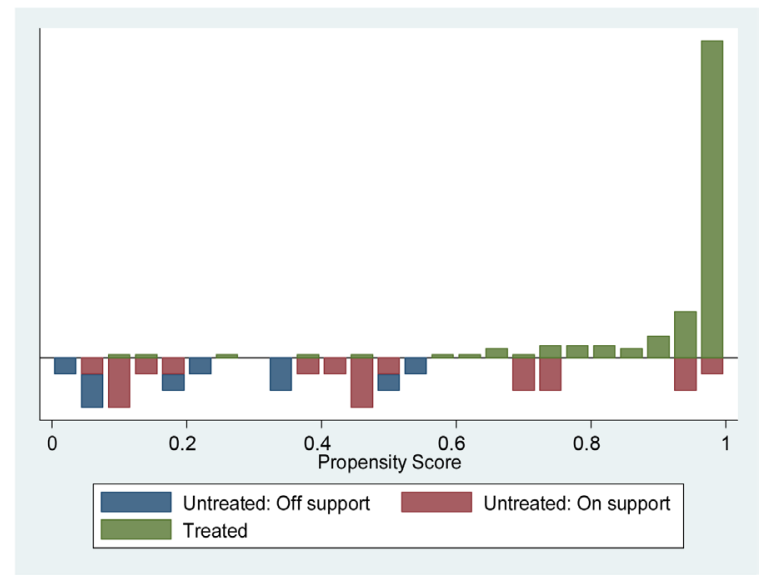

Figure 2. Distribution of density of propensity score estimates. 


\section{Conclusion and Recommendations}

This study focused mainly on the users of small scale irrigation technology on the crop yield and how irrigation technology contributed to the improvement of the crop income of the users in Rwanda through the average treatment effect on the treated approach. The study has substantiated that irrigation in the study area has significantly improved the crop yield, crop income to predict the future food expenses for food security. Therefore, irrigation technology use is not a substitute for other productivity enhancing factors rather a complementary factor. It is suggested to policy makers, implementers, and any funding agencies with similar interest to further capitalize and scale up the irrigation technology facilities and create more awareness in order to achieve improvement of livelihood outcomes of rural households, especially to offset the effect of drought regions which is mainly the Nasho sector. However, despite the positive impact of small scale irrigation technology to users, it contends that other sustainable irrigation sources, such as rainwater harvesting systems including ground water recharge through pit and tube wells as well as gabions system which are usually used to reduce but not to stop the speed of stream in erosion control, should be used due to possible environmental impact in the excessive use of irrigation technology.

\section{Acknowledgements}

The author would like to thank the Government of Rwanda through the Ministry of Agriculture and Animal Resources (MINAGRI) through its Institution Rwanda Agriculture and Animal Resources Development Board (RAB). Special thanks to Dr. Innocent NZEYIMANA (The Former head of department of Land Husbandry, Irrigation and Mechanization Department in Rwanda Agriculture and Animal Resources Development Board (RAB). My thanks also go to the field technicians who helped me to daily record the data, namely Aime Bosco Ntihabose, Umuhoza Marie Jeanne, Niyigena Devothe and Venuste Baziruwiha who contributed enormously in Data collection.

\section{Conflicts of Interest}

The authors declare no conflicts of interest regarding the publication of this paper.

\section{References}

[1] Smith, L.E. (2004) Assessment of the Contribution of Irrigation to Poverty Reduction and Sustainable Livelihoods. International Journal of Water Resources Development, 20, 243-257. https://doi.org/10.1080/0790062042000206084

[2] Tucker, J. and Yirgu, L. (2011) Water in Food Security Assessment and Drought Early Warning.

[3] Hussain, I. and Hanjra, M.A. (2004) Irrigation and Poverty Alleviation: Review of the Empirical Evidence. Irrigation and Drainage, 53, 1-15. https://doi.org/10.1002/ird.114 
[4] Foster, S., et al. (2000) Groundwater in Rural Development: Facing the Challenges of Supply and Resource Sustainability. The World Bank. https://doi.org/10.1596/0-8213-4703-9

[5] Dixon, J.A., et al. (2013) Economic Analysis of the Environmental Impacts of Development Projects. Routledge, London. https://doi.org/10.4324/9781315066240

[6] Giné, R. and Pérez-Foguet, A. (2008) Sustainability Assessment of National Rural Water Supply Program in Tanzania. Natural Resources Forum, 327-342. https://doi.org/10.1111/j.1477-8947.2008.00213.x

[7] FAO (2016) Agriculture Organization, 2014. Livestock Primary. Food and Agriculture Organization of the United Nations.

[8] Maddison, A. (2013) Economic Progress and Policy in Developing Countries. Routledge, London. https://doi.org/10.4324/9781315888422

[9] NISR (2016) Poverty Trend Analysis Report 2010/11-2013/14. National Institute of Statistics of Rwanda Kigali.

[10] Huggins, C.D. (2014) 'Control Grabbing' and Small-Scale Agricultural Intensification: Emerging Patterns of State-Facilitated 'Agricultural Investment' in Rwanda. Journal of Peasant Studies, 41, 365-384. https://doi.org/10.1080/03066150.2014.910765

[11] Ryan, T.P. (2013) Sample Size Determination and Power. John Wiley \& Sons, New York. https://doi.org/10.1002/9781118439241

[12] Addis, F., et al. (2016) Impacts of Smallholder Tree Plantation in Amhara Region of Ethiopia: The Case of Lay Gayint and Fagta Locuma Districts. Ethiopian Journal of Economics, 25, 35-58.

[13] Gebremariam, T. (2016) Adoption and Impact of Micro Irrigation on Households Income: The Case of Bambasi Woreda.

[14] Tesfaye, A., et al. (2008) The Impact of Small-Scale Irrigation on Household Food Security: The Case of Filtino and Godino Irrigation Schemes in Ethiopia. Irrigation and Drainage Systems, 22, 145-158. https://doi.org/10.1007/s10795-008-9047-5

[15] Becker, S.O., et al. (2010) Youth Emancipation and Perceived Job Insecurity of Parents and Children. Journal of Population Economics, 23, 1047-1071. https://doi.org/10.1007/s00148-008-0224-5 